\title{
COMMUNICATION
}

\section{Interview with Karen Saxe}

\section{Harriet Pollatsek}

\author{
Karen Saxe is the new director of the AMS Washington Office.
}

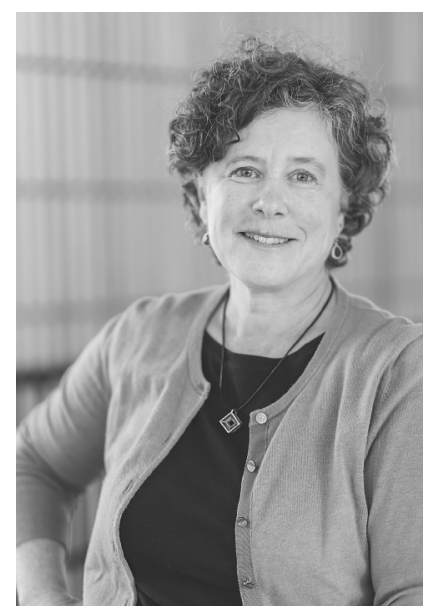

Karen Saxe is DeWitt

Wallace Professor

of Mathematics at

Macalester College. She

can be reached at saxe@

macalester. edu.
Pollatsek: What does the director of the Washington office do?

Saxe: It's all about communicating the beauty and importance of research in mathematics. The director helps the AMS develop a policy agenda and advocacy strategy, works with principal decision makers who impact science and education funding, and reports back to the AMS membership.

Pollatsek: Did your sabbatical year in Washington affect your interest in this job?

Saxe: When I spent the 2013-14 year in Washington, working for Senator Al Franken as the AMS Congressional Fellow, I learned first-hand how Congress operates and that I enjoy following legislation and policy discussions. I have always enjoyed working with lots of different people, and the fellowship year showed me that I could work with those in Washington. I hadn't been so sure about this given that I have always worked in academia, though I have volunteered time in Minnesota in local schools, with the League of Women Voters, and with local officials on redistricting, a mathematical interest of mine.

Pollatsek: What else attracted you to the director position?

Harriet Pollatsek is professor emerita of mathematics at Mount Holyoke College, and associate editor of Notices. Her email address is hpo11ats@mtholyoke.edu.

For permission to reprint this article, please contact: reprint-permission@ams.org.

DOI: http://dx.doi.org/10.1090/noti1443
Saxe: I wanted to work with AMS members and staff to continually update and refine our message about how mathematics is valuable for the nation and thus why it should be funded. I want to help stakeholders in Washington feel comfortable talking about mathematics and more generally to promote public understanding of the importance and impact of mathematics.

To be a strong advocate for our discipline, I look forward to establishing relations with AMS members to become more familiar with a broad range of mathematics at the frontiers of our collective knowledge. These relations will help me draw on the good will of AMS members when I need volunteers, for everything from Congressional briefings to grassroots advocacy.

Pollatsek: What is your previous experience working with the professional societies?

Saxe: I have been an active member of AMS, and also of AWM and MAA for many years. My most significant contribution has been in my recent service as a vice president of the MAA. I currently serve on the Science Policy Committees of both AWM and MAA. I have worked over the past year with several AMS members on policy-related issues via the NSF-funded Common Vision ${ }^{1}$ project, on which I am principal investigator, and also through my involvement on the Transforming Post-Secondary Education in Mathematics (TPSE Math) Board of Directors.

The one-year grant to the Common Vision project ends September 30, 2016. The work done during the first year we view as Phase 1 of a two-part process. We now have a one-year extension, to launch collaborative work between the MAA and NCTM as we move Common Vision forward into the proposed Phase 2, now dubbed "Common Vision: Taking Action." I see my role lessening significantly on Common Vision as other groups are spurred to action and develop projects. The TPSE work is much broader, and we are beginning our implementation phase. Tara Holm and I recently wrote an article for the 2016 June/July Notices about both of these projects and their relation to each

www.maa.org/common-vision 
other. ${ }^{2}$ I will continue my work on the TPSE Board.

Pollatsek: What challenges do you see as you take on this position?

Saxe: One challenge that impacts our profession is the general lack of understanding, and I would say "fear," of mathematics. This fear is evidenced by the outsized publicity given critics like Andrew Hacker [whose book The Math Myth was reviewed in the 2016 November Notices]. (Evelyn Lamb rebuts well his argument "that abstract math is scary, damaging, and should be optional in American education." 3 ) The fact that Hacker is able to get such media attention for his cause indicates that we have not done a good job presenting our field to the public.

Criticism of our community is not limited to naïve critics such as Hacker; Engage to Excel: Producing One Million Additional College Graduates with Degrees in Science, Technology, Engineering, and Mathematics (President's Council of Advisors on Science and Technology, 2012) also criticizes our collective enterprise. ${ }^{4}$ The challenges laid out in this report, together with the opportunities described in the more positive The Mathematical Sciences in 2025 (National Research Council, 2013) serve together as a call to action for our community to acknowledge the need for improvement as well as a platform from which to base improvement efforts. Common Vision and TPSE are just two examples of current initiatives launched in response to these two reports and aimed at encouraging and enabling positive change in the teaching of the mathematical sciences at the post-secondary level.

To present a better and more accurate image of what we do, I would like to increase the presence of mathematicians in the government sphere, at all levels. I am interested in increasing not only the number of senior members of our community in important posts within federal agencies, but also PhD mathematicians at all stages of their careers as AAAS Science and Technology Fellows (the fellowship that allowed me to serve Senator Franken), and even our undergraduate math majors as Congressional staffers and federal agency employees.

A second big challenge to our profession is a consequence of the fact that we are living in difficult fiscal times. Most AMS members are employed at institutions of higher education, many of which have been coping for several years with state disinvestment. Not only can lack of sufficient funds diminish the quality of our individual work lives, it can decrease the quality of the education offered our students and therefore negatively affect our pipeline of graduate students and post-doctoral fellows.

${ }^{2}$ Also see the opinion piece by Jorgensen in the 2016 November Notices.

3 www.s 1ate.com/articles/hea1th_and_science/ education/2016/03/andrew_hacker_s_the_math_myth_ is_a_great_example_of_mathematics_i11iteracy.htm1.

${ }^{4}$ See the October 2012 Notices for two articles about this report.
Mathematicians rely on NSF funding to support their research activities and this, too, has taken a hit in recent years. The NSF budget is determined by the House and Senate Appropriations Committees' respective subcommittees on Commerce, Justice, Science and Related Agencies. As of this interview, both the House and Senate appropriations bills have passed, and both propose disappointing 2017 budget levels for the NSF. I am looking forward to working annually through the Congressional appropriations process to secure funds to support research. Not only do we need higher levels of funding allocated each year, we need to continue to push for long-term stability of these funds to enable programmatic and infrastructure planning for continued growth. Because federal funding is an increasingly large source of support for mathematicians, AMS's engagement with the annual decision-making process is critical.

So far I have talked about the challenges of the job "from the outside." I know, too, that I face personal challenges as I take on this new job. Sam Rankin has held this position for over two decades; establishing relations as he has both within the AMS and also in Washington will require diligence and patience. And, I would be remiss if I didn't acknowledge a more emotional challenge-that I am moving away from teaching students and working with terrific colleagues developing programs and curricula, both of which I love and will miss.

Pollatsek: Any final comments?

Saxe: Being selected for this position to succeed Sam Rankin is an honor and a tremendous opportunity to serve the mathematics community.

For information on the federal budget process, check out these articles on the web:

\section{A Brief Guide to the Federal Budget and Appropriations Process Appropriations Watch: FY 2017 \\ Policy Basics: Introduction to the Federal Budget Process}

See these related Notices articles:

A Common Vision for Undergraduate Mathematics by Tara Holm and Karen Saxe, June/July, 2016. www . ams . org/publications/journals/notices/201606/ rnoti-p630.pdf

Review by David Bressoud of The Math Myth by Andrew Hacker, November, 2016.

Are Mathematics Faculty Ready for Common Vision? by Marcus Jorgensen, November, 2016.

\section{Credit}

Photo of Karen Saxe is courtesy of David Turner/Macalester College. 